\title{
A INVENÇÃO DA FAVELA INDUSTRIAL: PISTAS DA HISTÓRIA, MEMÓRIA E IDENTIDADE DO JACAREZINHO
}

\author{
THE INVENTION OF THE INDUSTRIAL FAVELA: CLUES OF JACAREZINHO'S \\ HISTORY, MEMORY AND IDENTITY
}

\section{LA INVENCIÓN DE LA FAVELA INDUSTRIAL: PISTAS DE LA HISTORIA, MEMORIA Y IDENTIDAD DE JACAREZINHO}

\author{
Jonas Abreu ${ }^{1}$ \\ 10.21665/2318-3888.v8n15p262-300
}

\section{RESUMO}

O presente artigo é resultado de pesquisa que investigou a construção da identidade cultural da Favela do Jacarezinho, em meio ao pano de fundo político e econômico do Rio de Janeiro. Utilizou-se o método de pesquisa exploratória com a finalidade de analisar a difusão dos elementos simbólicos que estão associados com a formação da identidade local. Para obter os resultados do estudo foi consultada extensa bibliografia nos campos da Sociologia, Antropologia e História da Cultura, assim como teses, dissertações, relatórios e documentos públicos. Os resultados deste exame apontaram para o desenvolvimento histórico e social da comunidade em três fases: na primeira, descrevemos a fundação e a expansão territorial da favela estimulados pela emergência do republicanismo e o incremento da industrialização na cidade. $\mathrm{Na}$ segunda fase, foram analisados os processos simbólicos construídos na favela através da relação dos moradores com as fábricas, o samba, entidades religiosas e movimentos políticos. Na terceira fase, apuramos um cenário disruptivo caracterizado pela decadência do espaço físico, violência institucionalizada e atravessado por fragmentos de cultura globalizada que inseridos em seu ecossistema social fragmentou as possibilidades identitárias da comunidade. Nossa principal hipótese é a de que atualmente a favela do Jacarezinho reproduz um perfil de privação de seus mitos de origem, como acontece nas novas paisagens transnacionais das periferias da América Latina.

Palavras-chave: Favela do Jacarezinho. Favela industrial. Identidade. Evolução urbana. Surgimento das favelas. General Electric.

\footnotetext{
${ }^{1}$ Mestre em Bens Culturais e Projetos Sociais pela FGV-RJ. Possui especialização em Marketing Estratégico pela Universidade Cândido Mendes e graduação em Turismo pela UniverCidade. Atualmente é coordenador técnico da Faetec Ipanema e professor da Universidade Anhanguera. Email: jonasabreu2008@hotmail.com.
} 


\begin{abstract}
This article is the result of research that investigated the construction of the cultural identity of the Favela do Jacarezinho, in the middle of the political and economic background of Rio de Janeiro. The exploratory research method was used in order to analyze the diffusion of symbolic elements that are associated with the formation of local identity. To obtain the results of the study, an extensive bibliography was consulted in the fields of Sociology, Anthropology and History of Culture, as well theses, dissertations, reports and public documents. The results of this examination pointed to the historical and social development of the community in three phases: in the first, we describe the foundation and territorial expansion of the favela stimulated by the emergence of republicanism and the increase of industrialization in the city. In the second phase, the symbolic processes built in the favela were analyzed through the relationship of residents with factories, samba, religious entities and political movements. In the third phase, we found a disruptive scenario characterized by the decay of physical space, institutionalized violence and crossed by fragments of globalized culture that inserted in its social ecosystem fragmented the identity possibilities of the community. Our main hypothesis is that currently the Jacarezinho favela reproduces a profile of deprivation of its myths of origin, as in the new transnational landscapes of the peripheries of Latin America.
\end{abstract}

Keywords: Favela Jacarezinho. Industrial Slum. Identity. Urban Evolution. Emergence of Slums. General Electric.

\title{
RESUMEN
}

Este artículo es el resultado de una investigación que investigó la construcción de la identidad cultural de la Favela do Jacarezinho, en medio del contexto político y económico de Río de Janeiro. El método de investigación exploratoria se utilizó para analizar la difusión de elementos simbólicos asociados con la formación de la identidad local. Para obtener los resultados del estudio, se consultó una extensa bibliografía en los campos de Sociología, Antropología e Historia de la Cultura, así como tesis, disertaciones, informes y documentos públicos. Los resultados de este examen señalaron el desarrollo histórico y social de la comunidad en tres fases: en la primera, describimos los cimientos y la expansión territorial de la favela estimulada por la aparición del republicanismo y el aumento de la industrialización en la ciudad. En la segunda fase, se analizaron los procesos simbolicos construidos en la favela a través de la relación de los residentes con fábricas, samba, entidades religiosas y movimientos políticos. En la tercera fase, encontramos un escenario disruptivo caracterizado por la decadencia del espacio físico, la violencia institucionalizada y atravesado por fragmentos de cultura globalizada que se insertaron en su ecosistema social fragmentando las posibilidades de identidad de la comunidad. Nuestra hipótesis principal es que actualmente la favela de Jacarezinho reproduce un perfil de privación de sus mitos de origen, como en los nuevos paisajes transnacionales de las periferias de América Latina.

Palabras clave: Jacarezinho Favela. Barrios Marginales Industriales. Identidad. Evolución Urbana. Emergencia de Los Barrios Bajos. General Electric. 


\section{Introdução}

A história e a construção da identidade da favela do Jacarezinho constituem o objeto deste estudo e possuem um pano de fundo que caminha junto às contradições da ocupação do espaço urbano da cidade do Rio de Janeiro. Para chegar até os fatos relacionados ao surgimento do local, precisamos compreender as formas de apropriação urbana que se desenvolveram no Rio de Janeiro, distribuídas em três séculos de colonização portuguesa. A estrutura de ocupação urbana seguiu o modelo núcleoperiferias, tendo sido resultado de um longo processo de evolução histórica.

Para identificar esse arranjo urbano, foram definidos alguns objetivos: relacionar as intervenções urbanísticas da região nas primeiras décadas do século XX, investigar o contexto político-social pelo qual surgiu e expandiu-se a comunidade, analisar a evolução dos modelos de identificação cultural assumidos pela favela e por fim, questionar as relações da fragmentação identitária atual da favela com a homogeneização da paisagem transnacional comum aos espaços periféricos da América Latina.

Para tal, precisamos seguir as pegadas de pesquisadores, antropólogos, sociólogos e historiadores que descreveram ou confirmaram a estrutura espacial segmentada da cidade, enquanto analisavam a paisagem cultural que se organizava. Por conta da opção pela metodologia de pesquisa exploratória, foi possível cumprir o propósito de sair em busca de padrões de acúmulo simbólico na comunidade, procurar ideias conflitantes ou descobrir hipóteses sob quais modelos foram mais assimilados. O objetivo não foi testar ou comprovar alguma teoria ou prognose, mas fazer descobertas à medida que a memória e a identidade foram sendo construídas.

Quantos aos resultados, parecem apontar para três fases distintas na trajetória da construção deste arcabouço de identidade imaginada. A etapa inicial demonstra o esforço coletivo pelo reconhecimento ao direito de permanecer assentados no local, contando para isso com o apoio das fábricas, entidades religiosas locais e de políticos engajados. A segunda etapa, a partir dos anos 1960, já sem a tutela federal e estabelecida territorialmente, a comunidade pode flertar com o samba e a política, enquanto a expansão geográfica ganhava contornos mais amplos. A etapa atual, delineada a partir 
dos anos 1990 descreve uma favela sem o esplendor das fábricas, carente de novos elos sólidos de pertencimento e enfraquecida pela violência territorializada, observando extrema fragmentação de suas representações socioculturais.

O artigo está dividido em seis seções. Inicialmente, na seção "Pistas a partir da espacialidade do Rio de Janeiro" traçamos o histórico da ocupação urbana da cidade, descrevendo a formação dos núcleos sociais nos espaços geográficos da cidade, durante o século XIX. Na segunda seção, "A fábula da República intensifica o surgimento das favelas" demonstrou-se de que forma a identidade republicana afrancesada projetada pelos governantes para a cidade deslocou os pobres e pretos para os morros próximos. "A invenção do Jacarezinho" permite identificar o surgimento da favela, potencializada pela implantação das indústrias na zona norte e por novos deslocamentos internos. $\mathrm{Na}$ quarta seção, "A favela chega à maioridade" é analisado o fenômeno da indústria da desapropriação que se acentua a partir das décadas de 1940 e 1950 e que foi usado como moeda de troca pelos antigos donos do território, políticos e a igreja na negociação por votos e consciências. Nesta fase consolida-se a divisão geográfica da favela. A seção "A fábrica, o samba e a política: Jacarezinho em busca de sua identidade" trata do acúmulo de simbolismos que consolida a identidade cultural da comunidade, centrado nas relações com as indústrias locais, na popularização do samba e nas disputas políticas em torno da Associação de Moradores. Na última seção "Nós, os favelados do asfalto" é possível argumentar sobre o processo de estratificação da identidade bairrista solidamente constituída nos anos anteriores e indaga-se sobre se podemos constatar nesta fragmentação a influência das mudanças da vida cotidiana e a reestruturação da esfera pública gerada pela indústria da comunicação e entretenimento.

\section{Pistas a partir da espacialidade do Rio de Janeiro}

O autor Mauricio de Abreu em seu livro Evolução Urbana do Rio de Janeiro (1987) confirma que a espacialidade do Rio era contida pelos morros do Castelo, São Bento, Santo Antônio e da Conceição, limitando o acesso às terras que se dirigiam ao sertão carioca - eufemismo que serve para caracterizar as freguesias da zona norte e oeste nos séculos XVIII e XIX. Até 1800, aproximadamente o núcleo central urbano poderia ser 
traçado a partir da atual Praça XV de Novembro, incluindo a região do Castelo e as ruas do Ouvidor e Uruguaiana, não ultrapassando os campos da cidade (Santana e São Cristóvão). O acesso ao mar poderia ser feito a partir das praias de Santa Luzia e Calabouço (próximas ao Morro do Castelo) e Prainha (adjacente ao Morro de São Bento), observando que a orla marítima ainda não era coberta pelos aterros ${ }^{2}$ que viriam alterar os limites da cidade no século XX.

A elite da cidade era composta por uma camada de funcionários administrativos, militares e comerciantes descendentes de portugueses, sendo a população predominantemente de origem escrava. Todos moravam nos mesmos espaços geográficos entre brejos e morros, sendo diferenciados apenas pela forma e aparência de suas casas. Em 1808 com a vinda da família real, novas atividades econômicas, políticas e ideológicas são incorporadas à cidade, que passa a exercer a sua capitalidade como sede do Reino Unido de Portugal, Brasil e Algarves em 1815. A nova função acarreta transações mercantis intensificadas pela expansão crescente da população livre e dos estrangeiros.

Por volta de 1850, o ciclo do café determinou uma nova lógica de ocupação ancorada em uma estratificação social que teria influências no espaço urbano. A burguesia cafeeira, em busca das mansões e residências que afirmassem o seu novo status se expande para os bairros da Glória, Botafogo, Largo do Machado e Tijuca, por meio dos bondes urbanos. A introdução desse tipo de veículo na cidade transformou o modo de vida e a estrutura viária. Para Maurício de Abreu (1987, p. 37) o transporte de massa permitiu o desafogo do centro, ampliando a malha urbana, ocasionando uma nova estruturação socioespacial da capital. O serviço de bondes iniciado em 1868,

${ }^{2}$ Os aterros permitiram a expansão da cidade, antes cercada de praias. No início do século $X X$, a de Santa Luzia era uma opção de lazer até o prefeito Pereira Passos mandar construir em 1905 garagens para os barcos dos clubes de remo. Em 1922, com a derrubada do Morro do Castelo, foi construída a Esplanada do Castelo e posteriormente (1940) o Aeroporto Santos Dumont. A construção do porto do Rio no século XX, acabou escondendo a Praia da Gamboa. As praias Dom Manuel e do Peixe, na Praça XV também deixaram de existir. Fonte: DiáriodoRio.com, 21 dez 2018. 
rapidamente se espalhou pelo centro e Tijuca com a proliferação das companhias de carris.

Uma delas, a Companhia Jardim Botânico atuava também em parceria com o capital imobiliário, uma vez que as linhas abriam espaço na zona sul, que seriam transformados em bairros. O ramal de Copacabana foi inaugurado com o tráfego de bondes movido à tração animal em 1892. (ABREU, 1987, p. 72)

Segundo Elisabeth Weid (1990, p. 41), o próximo passo nesta trilha de transformação das vias urbanas, foi a extensão a partir de 1905, das linhas de bondes da Igrejinha de Copacabana até Vila Ipanema, visando a abertura de espaços nobres de moradia. A prefeitura realizou obras de infraestrutura, arborização e espaços de lazer nesta área e o avanço continuou até o Leblon, loteada pela família Ludolf. Em 1918, a Companhia Jardim Botânico estendia suas linhas até o Leblon, operando bondes elétricos e fechando esse importante ciclo de intervenção urbana na zona sul. Deste modo, o bonde constituiu-se em um fator essencial no desenvolvimento do Rio de Janeiro e na setorização social, tanto por meio da expansão urbana do centro, como pela evolução das linhas de carris para os bairros mais famosos: Copacabana, Ipanema e Leblon.

Enquanto os bondes se expandiam em direção à zona sul e Tijuca, o trem a vapor atravessava o sertão carioca constituindo-se na opção para os assalariados. As estradas de ferro D. Pedro II, Rio d'Ouro, Auxiliar e Leopoldina começaram a partir da década de 1860 a ligar os subúrbios cariocas: São Francisco Xavier, Mangueira, Engenho Novo, Bonsucesso, Cascadura, Sapopemba (Deodoro) e Maxambomba (Nova Iguaçu). Quanto ao núcleo central original no entorno da Praça $\mathrm{XV}$ e ruas adjuntas, a área assistiu uma proliferação de cortiços e casas de cômodo, para manter os trabalhadores próximos da oferta de emprego. O processo de segmentação social que antes era identificado exclusivamente pelo acabamento dos sobrados ou fachadas das casas de seus proprietários, passa a um novo estágio de segregação consolidado agora em escala geográfica e sociocultural. Os bondes e os trens descongestionaram o centro possibilitando um arranjo didático do espaço urbano, que ao fim do século XIX incluía três núcleos na espacialidade sociocultural da cidade: 
1) A zona sul e a Tijuca ocupadas pela burguesia cafeeira e a elite urbana, conectava-se ao centro pelos serviços de carris, formando um grupo de moradores privilegiados. Neste novo espaço puderam capitalizar a ideologia da vida "moderna" difundida pelas empresas imobiliárias. O controle do capital especulativo da produção cafeeira era dividido por poucos e foi sendo transferido aos investidores estrangeiros sob a forma de monopólios que direcionavam para a zona sul as decisões sobre áreas que deveriam ser providas de serviço público. Capitaneadas pelos empresários do transporte, deslocaram para esta região a iluminação pública a gás, o recolhimento de lixo e esgoto, a abertura de ruas e loteamentos e os transportes coletivos.

2) Os subúrbios que cresceram a partir do Engenho Novo por meio das linhas férreas foram ocupados de forma lenta e progressiva pelos pobres e as camadas proletárias. $\mathrm{O}$ trem tornou-se o meio de transporte que permitia às classes populares o deslocamento entre a residência e o trabalho. Na região, não havia os serviços essenciais disponíveis na zona sul e centro. Uma leva de imigrantes vinda de outros estados e regiões afluía ao sertão carioca, ocupando as várzeas dos rios e os morros próximos às estações de trem que iam sendo inauguradas. O fato intensificou a divisão social, na busca das oportunidades da cidade-capital, que passaram a ser disputadas por moradores de várias origens.

3) No centro, além dos trabalhadores e comerciantes, uma base social mais pobre expandiu-se para incluir os escravos libertos, os desocupados, vendedores de rua, sapateiros, barbeiros e os imigrantes baianos e judeus. Todos ocupavam os cortiços ou as áreas mais afastadas, como Campo de Santana, Praça XI e a zona portuária, conhecidas como o "submundo" da cidade.

Durante este período, correspondente a expansão da revolução industrial do final do século XIX, a complexidade do mundo moderno passou a exigir que os sujeitos se identificassem com os valores e símbolos dos mundos que ele habitava. Stuart Hall analisou este processo afirmando que essa concepção interativa da identidade se contrapunha ao sujeito do Iluminismo do século XVIII, que se baseava em um "indivíduo totalmente centrado, unificado, dotado das capacidades de razão, de consciência e de ação" (HALL, 2006, p. 10). De acordo com esta nova visão, a identidade sociológica 
contribuía para alinhar os sentimentos subjetivos com os lugares objetivos que ocupávamos no mundo social e cultural. Desse modo, a busca por uma identidade afinada com as nações desenvolvidas da Europa, exigia um deslocamento geográfico dos empresários do café e da elite burguesa para os espaços que afirmassem seu prestígio. A ocupação da zona sul da cidade inaugura uma estratificação geográfica e social, mas também servia ao propósito de afirmar a esses sujeitos uma identidade. Essa equação cultural vivenciada à época, correspondia a uma idealização mais social do sujeito, porque a despeito de ter um núcleo interior, isto é, o "eu real", este era "formado e modificado num diálogo contínuo com os mundos culturais exteriores e as identidades que esses mundos oferecem." Isso corresponderia no entendimento de Hall à busca por uma "costura do sujeito à estrutura" (HALL, 2006, p. 11-12).

Do mesmo modo, se nossa hipótese estiver correta, os núcleos mais pobres se autoexcluíam deste novo espaço, pois atuavam em uma estrutura de poder cultural que garantia a hegemonia efetiva da cultura branca portuguesa localizada nos centros urbanos e áreas seletivas, por cima das culturais subalternas e regionais. Considerando que Ihes foram designadas as paisagens sociais na direção do resto da cidade, isso assegurava a sua conformidade subjetiva com as demandas objetivas da cultura dominante. Veremos adiante que esse processo no qual foram projetadas as identidades culturais da elite burguesa e dos pobres vão dar lugar a afinidades mais temporárias, diversificadas e problemáticas. Por ora, na transição dos séculos, podemos dizer que amadureciam as bases políticas e ideológicas que potencializariam as intervenções urbanas no início do século XX e possibilitariam o surgimento das favelas.

\section{A fábula da República intensifica o surgimento das favelas}

A cidade experimenta um intenso crescimento demográfico no final do século XIX por conta da diminuição da produção cafeeira nas regiões produtoras e da abolição da escravidão que liberam mão de obra desocupada e negros livres para a cidade. O início do desenvolvimento industrial do país contribui ainda mais para o processo de imigração, atraindo portugueses e europeus, fazendo inchar a área central que já experimentava grande concentração de cortiços, que aliás, passam a ser perseguidos e 
desocupados. Em 1893, aproximadamente 2 mil pessoas de uma área próxima à Central do Brasil são expulsas durante a destruição do "Cabeça de Porco" - o maior cortiço da cidade. Os ex-moradores, entretanto, conseguem permissão para construir suas casas no Morro da Providência, na região portuária. O Morro de Santo Antônio também recebe os soldados que lutaram na Revolta da Armada - um movimento da Marinha contra os governos autoritários de Marechal Deodoro e Floriano Peixoto. Para completar, cerca de 20 mil soldados retornados ao Rio após a Guerra dos Canudos na Bahia, também começam a habitar o Morro da Providência. A partir da década de 1920, estes morros cobertos por barracos e casebres passaram a ser chamados de "favelas", sendo vistos como área de criminalidade e doenças.

Concomitantemente a este processo de depreciação das encostas dos morros do centro, desenvolveu-se um movimento contrário de valorização da parte urbana ocupada da cidade. O motor deste movimento foi a invenção da República em 1889. Segundo Jonas Abreu (2014) após a sua proclamação, ainda faltava inventar a cidade republicana, buscar um sentido de nacionalidade para o país e cultivar nos moradores este senso de pertencimento. Apoiado no plano do governo federal, a cidade precisava ser reformada para se tornar o modelo da "Paris dos trópicos" inspirada nas intervenções urbanas bem conduzidas pelo Barão Haussmann na capital francesa, em décadas anteriores. Para esse fim, o prefeito Pereira Passos produziu entre 1902 e 1906 reformulações urbanas no centro da cidade, que incluiu desde a abertura e ampliação de novas vias, como a Avenida Central (atual Rio Branco) até a reconstrução do porto da cidade, para servir como escoadouro moderno da produção cafeeira. (ABREU, 2014, p. 33).

O estilo afrancesado da cidade foi materializado tanto nas edificações da nova Avenida Central, como na construção de seis palacetes neoclássicos e ecléticos no entorno da Praça Mal. Floriano, área da futura Cinelândia ${ }^{3}$. Consolidou-se assim o longo período de supremacia francesa na arquitetura da cidade iniciado ainda nos tempos do Império, seguindo agora as linhas gerais da Belle Époque e gerando um legado cultural que

\footnotetext{
${ }^{3}$ A lista dos palacetes inclui: Teatro Municipal, Museu Nacional de Belas Artes, Biblioteca Nacional, Prédio do Supremo Tribunal Federal, Palácio Pedro Ernesto e Palácio Monroe - demolido em 1976. Ver Abreu, J. Rio partido: a guerra das identidades, 2014.
} 
serviria ao propósito de um ambiente urbano europeu pensado pelas elites políticas e sociais para a cidade.

As demolições dos cortiços restantes obrigaram os moradores a buscar novas alternativas para construir suas casas, ocupando os morros próximos. Uma vez que as casas do antigo núcleo central estavam se valorizando cada vez mais, potencializou-se uma forte expansão das favelas também na direção da zona norte da metrópole (ABREU, 2014, p. 30)

A revalorização do Centro segue seu curso eliminando o espaço das habitações populares consoante ao que ocorria desde os tempos finais da transição do Império, mas a estratificação social nos primeiros anos da República vai se tornando dramática no espaço urbano à medida que os desalojados construíam novos casebres com os restos das demolições nas encostas do Morro da Providência e do Castelo.

A historiadora Lúcia Lippi Oliveira (2008) atesta que a construção da identidade política republicana e cosmopolita pretendida pelo poder público não se concretizou uniformemente em toda a extensão da cidade. A convivência da elite com as práticas e rituais da população periférica e suburbana permitia destacar a cultura "marginal" em meio ao contexto da modernidade que se implantava no Rio de Janeiro. (OLIVEIRA, 2008, p. 58-61)

Esse modelo sociológico interativo, conforme Hall prescreveu em seus estudos sobre a identidade pós-moderna, estabeleceu uma reciprocidade estável entre "interior" e "exterior" e serviu muito bem na primeira metade do século XX às teorias interacionistas que davam conta de como os indivíduos "são formados subjetivamente através de sua participação em relações sociais mais amplas e inversamente, do modo como os processos e as estruturas são sustentados pelos papéis que os indivíduos neles desempenham" (HALL, 2006, p. 31).

Estudando a sociologia, como produto do século XIX, Hall (2006, p. 31-33) localizou o indivíduo nos grupos sociais e teceu uma crítica ao individualismo racional cartesiano, consolidado no lluminismo. No início do século XX, o cenário da cidade sobre o qual elaboramos as narrativas deste artigo é o palco quase perfeito para compararmos a figura 
do indivíduo isolado, alienado, frente à metrópole anônima e impessoal conforme descrito por Hall (2006, p. 32) e aplicar à paisagem na qual estava se tornando o Rio de Janeiro.

Uma outra cidade se construía para além da cidade oficial. Este quadro pode ser atestado pela pungente sociedade alternativa que se formava nos arredores da cidade, provocando um deslocamento ou ruptura na identidade republicana até então, projetada como estável.

Mônica Veloso (1996, p. 21-34)) interpretava essa parte do Rio presente nos bairros e nos lugares marginais do centro que teimava ignorar a modernidade, especialmente representada pelos humoristas e caricaturistas cariocas que captaram as contradições aludidas à cidade e fizeram dessas deficiências o contraponto dessa alegação. Em suas pesquisas, Velloso (1996) encontrou esta refutação em publicações como D. Quixote e Revista da Semana ou periódicos como o Jornal do Brasil. A pesquisa das obras de alguns caricaturistas como J. Carlos, Kalixto e Raul Pederneiras permitiu à autora desenhar o imaginário constitutivo da própria nacionalidade a partir da elaboração de outra narrativa do cotidiano e da memória cultural do Rio de Janeiro.

A cidadania marginal encontrada no Rio de Janeiro e que destoava da ordem e valores que marca a tradição modernizadora do início do século XX apontava para uma cidade cingida desde as exclusões sociais dos tempos da implantação da República no final do século XIX. Alguns cronistas e humoristas como Lima Barreto, João do Rio e Raul Pederneiras apontavam a contradição entre esta modernidade e as formas de participação política paralela da população. Velloso (1996, p. 25) cita, por exemplo, a pesquisa efetuada junto às mulheres baianas - as "tias" - nos espaços comunitários.

Paulo Barreto (1976) conhecido por João do Rio foi um dos que pesquisou as demonstrações da periferia que existiam para além do Campo de Santana. Descreveu as manifestações religiosas observando cuidadosamente as canções africanas e as modinhas que eram representadas em um "submundo" recheado de presidiários, mendigos e prostitutas que habitavam os bairros da cidade. Abreu (2014, p. 39) confirma que "estas expressões populares estavam, por volta de 1910, integradas a um mercado 
semiprofissional que incluía cantores, músicos, dançarinos e atores que obtém parte de seu sustento vivendo destas atividades."

Estamos diante de um quadro contraditório e avassalador. O Rio de Janeiro como capital do Brasil era visto como o sustentáculo dos símbolos e representações nacionais, sendo natural que uma "cultura nacional" tenha sido emanada a partir dos discursos que influenciaram e organizaram os sentidos do que a classe política dominante projetava para a cidade. Como o ponto de partida era baseado nas concepções interiores da elite política sobre o mundo exterior construíram-se sentidos baseados nesta externalidade, com os quais poderíamos nos identificar. Esta lógica está coerente com o argumento de Anderson (1983, p. 32) quando afirma que a identidade nacional é uma "comunidade imaginada". Ele diz que a nação é imaginada porque "mesmo os membros da mais minúscula das nações jamais conhecerão, encontrarão, ou sequer ouvirão falar da maioria de seus companheiros, embora todos tenham em mente a imagem viva da comunhão entre eles". Powell (1969, p. 245) já havia expressado que "a vida das nações, da mesma forma que a dos homens, é vivida em grande parte, na imaginação".

Tomando como base esses fundamentos teóricos, podemos indagar o que teria dado errado no projeto de unificação nacional pensado pela elite político-burguesa pelo qual os brasileiros imaginariam pertencer. Nossa hipótese é que os elementos que caracterizaram a proposta da identidade republicana modernizadora para o Rio careciam de narrativas da nação, ênfases em origens nacionais, invenção de tradições, mitos de fundação ou discursos defensores de um suposto "povo original", ou seja, tudo aquilo que cientistas sociais, como Stuart Hall (2006), advogavam como essenciais para caracterizar uma cultura nacional. Neste sentido, ele chama a atenção para o fato de que esse discurso estruturante não seria tão moderno assim, e reforça que

as culturas nacionais são tentadas, algumas vezes a se voltar para o passado, a recuar defensivamente para aquele tempo perdido, quando a nação era grande; são tentadas e restaurar as identidades passadas. Este constitui o elemento regressivo, anacrônico, da estória da cultura nacional. (HALL, 2006, p. 56)

$\mathrm{Na}$ falta destes elementos, não teria sido possível uma engenharia construtiva unificadora em torno da modernidade republicana em qualquer das dimensões que se queira abordar. Na perspectiva arquitetural os palácios neoclássicos e ecléticos "afrancesados" 
de Botafogo, Laranjeiras, Catete e posteriormente da Praça Marechal Floriano espelhavam uma monumentalidade incapaz de ser absorvida pelo transeunte ou morador comum da cidade, sendo útil às camadas medias da população identificadas com a paisagem francesa.

No plano social, a valorização da zona sul e das novas áreas centrais acompanhadas pela abertura da Avenida Central e a modernização do porto, não permitiram formular um alicerce que unificasse os sentidos da nação, pois as representações giravam em torno de uma cidade alinhada com a modernidade europeia, convergindo para dentro da sociedade escravista brasileira os atributos "estrangeiros" da modernidade francesa, portuguesa e até inglesa.

\section{A invenção do Jacarezinho}

Seguindo a trilha da expansão da cidade, na direção de São Cristóvão e Engenho Novo, percebemos como as expressões culturais "menos nobres" do centro da cidade, embora consideradas alternativas, constroem um poderoso tecido social em oposição à cidade oficial edificada no entorno da Avenida Central. É para lá que caminhamos na tentativa de compreendermos melhor a lógica da construção das memórias dos subúrbios cariocas e a expansão das favelas no espaço comum da zona norte.

O autor Brasil Gerson (2000) pesquisou incansavelmente as origens das ruas do Rio de Janeiro e traça algumas pistas sobre como se desenvolveu a ocupação do entorno de Engenho Novo, Benfica, Jacaré e Sampaio, que nos ajudam a entender tanto a ocupação espacial destes bairros quanto a elaboração do composto sociocultural das favelas que migram para a zona norte, como Jacarezinho e Mangueira, por exemplo. O surgimento dos subúrbios e a expansão das favelas devem ser analisados como um fenômeno entrelaçado, ou melhor, composto de duas faces de uma mesma moeda. Na transição do século XIX para o XX, uma próspera combinação de usos na área central, por meio da ocupação de espaços pelo poder público e a busca por usos mais lucrativos pela iniciativa privada, resulta que os empreendedores dos negócios mais rentáveis saem vencedores, se reproduzem sob um modelo uniformizador e expulsam os demais tipos 
de usos. Nos anos seguintes, embora guarde semelhanças com o surgimento dos cortiços e favelas do centro, a expansão da cidade para o sertão carioca e a eclosão das favelas nesta região possui novas motivações que precisam ser identificadas à luz da industrialização e das recentes vias de circulação entre o centro e a periferia.

Segundo o autor, do ponto de vista do acesso por trem, os subúrbios principiavam na área compreendida por São Francisco Xavier e Engenho Novo, alcançados pela Estrada de Ferro Central do Brasil (GERSON, 2000, p. 420). Por outro lado, observando o processo de ocupação da cidade, o autor considera o "Engenho Novo da Companhia de Jesus", construído em 1707, como o ponto de partida do que se costumava identificar na época como "sertão carioca". A Capela dedicada a São Miguel e à N. S. da Conceição construída pelos jesuítas, em 1720, é um marco do patrimônio histórico desta ordem religiosa na zona norte (GERSON, 2000, p. 416). A partir do engenho as terras dos jesuítas neste perímetro incluíam a Serra dos Pretos Forros, a praia Pequena, em Benfica e adentrava até os limites do Engenho de Dentro. Isso atestava a amplitude das vastas lavouras e canaviais dos jesuítas antes de sua expulsão do Brasil, por ordem do Marquês de Pombal. Com a expulsão, as chácaras e sítios foram loteados e ruas foram abertas nos terrenos pantanosos, cortados pelo rio Jacaré que atravessa a localidade. O nome do rio seria uma corruptela de Yacaré (torto, sinuoso), por conta das voltas que dava. Grandes proprietários como Paim Pamplona e Adriano Müller lotearam o Jacaré fazendo surgir as ruas principais - Dois de Maio e Lino Teixeira. A partir da década de 1920 o bairro passa a ser urbanizado e ocupado.

Nesta época, descendo a Rua Dois de Maio, no Engenho Novo, em direção à Rua Lino Teixeira, poderíamos encontrar o Rio Jacaré e seguindo à esquerda deste rio, nos depararíamos com uma área na qual em torno do seu aclive pouco acentuado se localizava a Concórdia Sociedade Imobiliária e a Fábrica Unidas de tecidos, rendas e bordados. Estas duas empresas ocupavam a maior parte do espaço da atual Favela do Jacarezinho e teriam surgido do arrendamento da chácara Fazenda Velha, que desde o final do século XIX cultivava lavouras de legumes, hortaliças e frutas.

Não são muito claras as origens da invasão de parte destas terras pelos primeiros grupos de grileiros e favelados na década de 1920. O fato é que no coração da favela, existe 
uma praça de nome "Concórdia" que provavelmente é um resquício histórico de memória e identidade ligado aos mitos de fundação da comunidade, em referência a antiga empresa, cujo espaço teria sido apoderado pelos primeiros moradores. $\mathrm{O}$ pesquisador Rafael Gonçalves (2013) relata a tensão vivida pelos moradores e o poder municipal, duas décadas depois quando a Concórdia entra com o pedido de reintegração de posse de suas terras.

Antes da ocupação deste núcleo em torno da Praça da Concórdia, os primeiros assentamentos parecem ter sido associados ao surgimento da localidade Vieira Fazenda, alcançada pela Estrada Real de Santa Cruz, atual Av. D. Hélder Câmara (ex Avenida Suburbana). Originalmente esta via fazia parte do Caminho Imperial, que ligava o Município da Corte à Sepetiba. Atualmente, este é um dos principais eixos viários da zona norte do Rio de Janeiro, cuja extensão de 11 km, inicia-se no bairro de Benfica e até chegar a Cascadura, corta os bairros de Jacarezinho, Manguinhos, Maria da Graça, Del Castilho, Cachambi, Engenho de Dentro, Pilares, Abolição, Piedade e Quintino Bocaiúva.

O nome do local deriva da Estação de trem Vieira Fazenda, inaugurada em 1895, e que fazia uma homenagem ao famoso vereador, médico e historiador da época. Segundo Gerson (2000, p. 420), a linha férrea corria em frente às praias Pequena e Grande, em Benfica e "os trens cargueiros da Estrada de Ferro Rio D’Ouro, saídos do Caju trafegavam pela Rua da Alegria a dois passos do mar, à procura de terra firme perto de Triagem". Ao que tudo indica, as invasões no território onde fica atualmente o bairro de Jacarezinho iniciaram-se um pouco antes da década de 1920, a partir desta área demarcada pela linha do trem, abrangendo um perímetro entre o Rio Jacaré, a Estrada Real de Santa Cruz e os limites da fábrica de fósforos Cruzeiro. Nesta extensão foram sendo incluídos os assentamentos em torno de Vieira Fazenda e ao redor das empresas Concórdia e Unidas. A Cruzeiro parece ter sido a primeira indústria de maior porte inaugurada no local, responsável pela atração e recrutamento de imigrantes, antes da inauguração da gigante americana General Eletric.

O crescimento da favela do Jacarezinho foi sendo consolidado em função das instalações das indústrias no entorno da região, mas também da proximidade com a 
linha férrea. É preciso considerar que esta área é muito próxima ao centro da cidade e às localidades vizinhas que se industrializavam como Maria da Graça e Jacaré.

Podemos supor que o marco histórico que vai transformar esta área de vocação agrícola em um "cluster" industrial é a decisão da General Electric, em 1919 de investir na América Latina como parte da expansão americana na região. Comentando a respeito, o editor André de Court mencionava em seu website $(2011)^{4}$ que a vinda da General Electric era uma consequência direta dos ciclos de industrialização após a I guerra mundial, ocasionado pela escassez de componentes elétricos, especialmente lâmpadas e acessórios de iluminação. A fábrica foi instalada paralelamente aos trilhos da Linha Auxiliar margeando o bairro de Maria da Graça que estava sendo ocupado com as ruas Miguel Ângelo, Sabino dos Reis e Professor Bôscoli, todas ainda de terra batida ou incompletas. No espaço da futura favela do Jacarezinho, que se expandiria pelo lado interno da GE, existia um enorme terreno vazio que aguardava a construção de um pátio de cargas e manobras da Central do Brasil, nunca realizado. Magno Neves $(2012)^{5}$ cita no website Acervo.Racismoambiental que a localização da unidade da GE guardava uma distância de 15k, do centro do Rio de Janeiro, em uma área de uso misto, ainda que predominantemente residencial. A propriedade ocupava o topo da colina, tinha um formato irregular, mas se aproximava de um retângulo, apresentando declives voltados para nordeste e sudeste, na direção da Favela do Jacarezinho e outro voltado para noroeste, na direção do bairro Maria da Graça. O Rio Jacaré, hoje canalizado, corria aproximadamente a 300 metros ao sul da unidade, conectando-se ao Rio Faria e posteriormente ao Canal do Cunha, que deságua na Baía de Guanabara.

\footnotetext{
4 Informação obtida no website Foiumrioquepassou.com.br do editor André de Court, publicado em 30/3/2011.

5 Informação obtida no website Acervo.racismoambiental.net em artigo publicado pelo colaborador Magno Alves, em 16/6/2012.
} 


\section{A favela chega à maioridade}

Segundo o historiador Fábio Tavares $(2019)^{6}$ que criou um blog exclusivo para narrar a história da comunidade, a toponímia da favela apresenta uma trajetória circunscrita aos relatos orais. Na publicação eletrônica, ele relata depoimentos de muitos moradores na faixa etária acima de 80 anos, desde que a localidade era conhecida como "Mato do Padre Paulo" e "Morro da Titica". Cruzando os depoimentos com os jornais da época, identificou que o nome "Favela do Jacarezinho" começou a ser registrado a partir dos anos 1940.

Um destes depoimentos confirma que foram encontrados dois jacarés pelos moradores nas margens do Rio que corta a comunidade, sendo esse o mito de origem mais aceito para a denominação do local. Ainda segundo o pesquisador, vários moradores atestam que durante a limpeza dos terrenos visando à construção de suas residências, não era raro encontrar grilhões de escravos, ossos e outros artefatos que confirmariam a utilização de serviço escravo nos sítios locais no fim do século XIX.

A General Electric atraiu para o seu corpo de empregados milhares de moradores de Vieira Fazenda e do Cruzeiro, estabelecendo uma relação tão próxima quanto pudesse na tentativa de obter mão de obra barata e próxima ao local de moradia dos funcionários. Outras fábricas estavam sendo estabelecidas, com destaque para a Cisper, uma indústria de vidros fundada em 1917 no bairro do Jacaré. O maior de seus clientes neste início, a Cervejaria Brahma, foi fundamental para a consolidação da empresa, pois seu presidente Heinrich Künning encomendou 100 mil garrafas em 1918, permitindo o fornecimento em larga escala, uma novidade para a cervejaria que ainda comprava de pequenos fabricantes. A empresa segue contratando mão de obra da região e crescendo à medida que as Ruas Viúva Cláudio e Lino Teixeira, vizinhas da fábrica, seguem sendo urbanizadas. Nos anos 1960, a Owens Illinois, empresa americana com sede no estado de Ohio adquire $80 \%$ da companhia e o restante permanece com o grupo Monteiro Aranha, os primeiros investidores ${ }^{7}$. Assim como a General Electric, a Cisper junta-se a

\footnotetext{
${ }^{6} \mathrm{O}$ historiador Fábio Tavares criou o website jacarezinhorj.blogspot.com para relatar os fatos históricos a respeito do local. Estes dados foram obtidos do seu texto original datado de 6/10/2019

7 Informações obtidas no website do CECTH - Centro de Estudos do Corpo e Terapias Holísticas no boletim sobre a SIPAT 2006 - Promoção de "quick massage" (massagens) para os colaboradores da Owens Ilinois.
} 
outros empresários que nos seus diversos segmentos, (bens de consumo, de produção e manufaturados) encontram nos terrenos próximos das estradas de ferro e das vias recentemente urbanizadas da zona norte, os espaços ideais para a expansão de seus negócios.

Este processo de expansão industrial acarreta o incremento da imigração, que tendo se iniciado timidamente nos anos 1920 com a transferência interna de moradores do centro e da região portuária, passa a englobar nas décadas seguintes os solteiros e posteriormente suas famílias de outros estados. Os migrantes procedem em sua maioria do noroeste do Estado do Rio, das cidades rurais do Espírito Santo e Minas Gerais, além de expressivo contingente de nordestinos, especialmente baianos e pernambucanos.

A maior parte dos imigrantes foi atraída por conta do grande impulso das invasões e da estimulação de grileiros. Gonçalves (2013) analisa o fenômeno da indústria da desapropriação que se acentua a partir das décadas de 1940 e 1950 em quase todos os terrenos onde proliferou algum tipo de apropriação ilegal ou consentida. No Jacarezinho isso toma proporções ainda maiores, devido ao fato de que a favela já era considerada a maior do Rio de Janeiro. Os jornais da época ressaltam a ação violenta de grileiros que reivindicam aluguel por casas e terrenos ocupados pelos favelados ou estimulam a ocupação para a cobrança de taxas posteriores. É notória igualmente a ação dos legítimos proprietários que celebraram contratos de aluguel com os invasores, mas sem a garantia de que não solicitariam a desapropriação. Segundo o autor, a maior parte das invasões antes de 1964, teria sido na verdade, concluída com algum consentimento dos grileiros, funcionários públicos e até dos proprietários. Em 1949, a empresa Concórdia Imobiliária reivindicou a reintegração de posse dos seus terrenos invadidos, correspondentes à antiga Fazenda Velha, mas como a prefeitura negou e ainda desapropriou as terras ${ }^{8}$, a empresa reagiu, solicitando ao poder judiciário, a indenização imediata, que ainda não havia sido paga. Muitas destas empresas estimuladas pelo artigo 347 do Código de Obras de 1937, que impediam remoções exceto no caso da construção de moradias substitutivas, solicitavam dos governos a indenização pela

\footnotetext{
${ }^{8}$ O decreto municipal no 9765 de 12 de maio de 1949 expedido pelo prefeito Mendes de Morais tratava da efetivação das diligências de desapropriação e solicitava ao juiz Augusto de Morais a anulação das medidas de expulsão dos favelados.
} 
ocupação ao invés da desapropriação. Agindo assim, conseguiam um comprador imediato para suas terras - o poder público - que pressionado pela opinião pública e o poder judiciário, procuravam obter compensações. A moeda de troca era o provável somatório de votos da comunidade nos pleitos políticos municipais e federais ancorada nos benefícios da autorização para os assentamentos. Os vereadores Edgard de Carvalho, Cotrim Neto e Geraldo Moreira foram alguns dos que aproveitaram este episódio para defender os favelados através da intermediação junto à Câmara dos Vereadores, redigir artigos na imprensa ou defender oficialmente os moradores na causa direta da desapropriação. Organizações como a Cruzada São Sebastião e a Fundação Leão XIII, ligadas à Igreja Católica também apoiavam a causa dos moradores.

Em sua tese de mestrado, a pesquisadora Cristiane Thiago (2007, p. 44) ${ }^{9}$ atesta a importância da ordem dos padres Salesianos que iniciam em 1960 a construção do templo católico N.S. Auxiliadora no alto da colina do Cruzeiro ocupada por barracos até o declive da antiga Fazenda Velha. A construção de alvenaria, iniciaria um período de parceria entre a comunidade e a igreja, liderada pelo Padre Nelson Carlos del Monaco, no sentido de construírem um discurso único junto ao poder público para a manutenção dos moradores no local. Os depoimentos colhidos pela pesquisadora em sua dissertação de mestrado, se somam às informações obtidas pelo historiador Fábio Tavares, (2019) ${ }^{10}$ que em seu blog "Jacarezinho.blogstpot" confirma que além da Igreja Católica, desde 1946, a Igreja Batista de Vieira Fazenda sob a liderança do pastor Anthidio Dias da Silveira, já se posicionava de forma favorável à permanência da população na parte baixa da favela, sem o ônus da desapropriação. Estes apoios tornaram-se essenciais para produzir na população uma percepção de maior segurança quanto ao temor de expulsão dos moradores.

As localidades internas da comunidade eram batizadas de acordo com seus traços históricos ou topográficos, construindo uma memória residual que evoca os traços de convivência social interna do Jacarezinho. A XXVIII Região Administrativa a qual

\footnotetext{
${ }^{9}$ Informações obtidas na dissertação de mestrado da pesquisadora Cristiane Tiago através do Programa de Pós-graduação em Memória Social da Universidade Federal do Estado do Rio de Janeiro - UNIRIO, 2007. 10 Dados do historiador Fábio Tavares em seu website jacarezinhorj.blogspot.com publicados em $6 / 10 / 2019$
} 
pertence atualmente o bairro, por meio dos técnicos da Coordenadoria de Programação e Projetos da Secretaria Municipal de Habitação, no âmbito do Programa Favela-Bairro, reconheceu esta delimitação do bairro e o dividiu em sete setores a partir de consulta aos próprios moradores: Beira-Rio, Fundão, Azul, Cajueiro, Cruzeiro, Fazenda Velha e Vieira Fazenda ${ }^{11}$.

O Largo do Cruzeiro foi se tornando a área central da comunidade, na qual se construiu a vida social da favela. As construções possuem um padrão construtivo formal, o comércio é variado e nela se encontravam as sedes da Fundação Leão XIII e do Clube do "Mosquito". A partir do Cruzeiro, se estende a Fazenda Velha, onde existia a antiga sede da fazenda e cuja extensão ao longo do declive, abrange as duas igrejas mais tradicionais do local: no alto, a Igreja Católica e na região baixa, a Batista de Vieira Fazenda. O setor chamado Beira-Rio foi estigmatizado como o mais "pobre" da comunidade, pois até a realização da canalização do rio Jacaré, as construções de palafitas desafiavam as enchentes. No Fundão, a principal característica são os alagamentos, que mesmo após as obras de canalização continuaram. A localidade chamada $A z u l$, na parte mais alta da comunidade, margeando o muro da General Electric, foi definida como tradicional e tranquila, tendo sido construídos fortes laços de vizinhança entre os moradores. A área é desprovida de uma rede comercial mais intensa como no Cruzeiro e em Vieira Fazenda. O Cajueiro é uma zona intermediária de uso misto - comercial e residencial - com urbanização relativa e significativa circulação de pedestres. Por último o território de Vieira Fazenda, parte interna mais desenvolvida comercialmente e de forte atração externa é a zona mais verticalizada da favela, também a de maior densidade demográfica. O fluxo de pedestres foi se intensificado pela conexão com as vias de transporte na Avenida D. Helder Câmara, a estação de metrô de Maria da Graça e a favela de Manguinhos.

Nas décadas de 1930 e 1940 as ocupações ocorriam praticamente nas sete áreas descritas anteriormente, sendo uma parte da Beira-Rio em torno da Praça XV de agosto, a última a ser efetivamente apropriada.

11 Os dados fazem parte do Documento 3412 do DataRio - Instituto Pereira Passos. Coleção Estudos Cariocas: breve relato sobre a formação das divisões administrativas na Cidade do Rio de Janeiro, 2010. 


\section{A fábrica, o samba e a política: Jacarezinho em busca de sua identidade}

O alargamento do Jacarezinho que caminhava em um ritmo mais hesitante, recebe um novo impulso em 1961. O governador Carlos Lacerda decretou a criação do Complexo Industrial do Jacaré, tornando as ruas Viúva Cláudio, Bráulio Cordeiro e mais 13 ruas do bairro, um celeiro para a captação de indústrias de calçados, bolsas, laboratórios farmacêuticos, fábricas de vidros e roupas, metalúrgicas, indústrias de café e de bens de produção. ${ }^{12}$ No final da década o Jacaré já tinha se transformado no segundo maior parque industrial do município, ficando atrás apenas de São Cristóvão. Seguindo a tendência do processo de industrialização da zona norte, a multiplicação das fábricas ajudou a consolidar a vocação tecnicista dos bairros vizinhos como Maria da Graça e Triagem que seguiram a trilha do Jacaré, na mesma rota de intensa proliferação fabril e incorporou uma nova paisagem de manufaturas em bairros até então residenciais, como Sampaio, Riachuelo e Cachambi.

Nos anos 1960 os eixos principais no sentido longitudinal já estavam definidos: na parte baixa a partir de Vieira Fazenda correm as ruas Comendador Gracindo de Sá e Amaro Rangel. Na parte alta as ruas Darcy Vargas e Esperança comandam os espaços residenciais e comerciais. Duas vias importantes surgiram na região que margeava o Rio Jacaré, a Av. Guanabara e Rua do Rio. A partir destes eixos, as vias secundárias são formadas por becos e vielas transversais.

A diferença entre as primeiras décadas do passado e os anos posteriores a 1960 é a chave para compreender o ambíguo consenso que emerge entre os moradores, as fábricas e as igrejas. Com as vias de circulação estabelecidas e o "fantasma" da expulsão definitivamente afastado, os elos comunitários caminham para outras demandas, em consonância com novos fatores de identidade social expressos em três perspectivas: a relação dos moradores com as indústrias, as manifestações culturais ligadas ao samba e a militância política de esquerda.

12 Dados obtidos no portal da Fundação Instituto de Geotécnica - Geo-Rio - órgão da Secretaria Municipal de Obras responsável pela contenção de encostas. 
Estes elos comunitários presentes nas décadas posteriores ao surgimento da favela, estão mais coerentes com a matriz de significados culturais que formulava os eixos de nossa cultura nacional, que durante a era Getúlio Vargas, seriam focados no samba e futebol. O sistema de representação caminhava para uma identidade unificadora, em torno da grande família nacional na qual o estado-nação se junta a natio - referenciada nas comunidades locais, domiciliares, ou seja, uma condição de pertencimento para as localidades, conforme estudado por Timothy Brennan (1990, p. 45). Isso nos possibilita supor que ao invés da contradição "submundo x cidade oficial" vivenciada na passagem do milênio, poderíamos estabelecer condições de pertencimento para as camadas periféricas na busca por uma unidade entre a esfera política e cultural. Deste modo, a cultura subalterna do "sertão carioca" ou das favelas do início do século XX, não estão mais nos anos 1960 em oposição a alguma suposta "identidade oficial republicana". Agora estariam inseridas em uma estrutura de poder cultural, na qual culturas estigmatizadas como as de origem africana ou nordestina, migrados para a favela, são unificadas por um atribulado processo de supressão da diferença cultural. Na verdade, as nações são compostas de distintas classes sociais, etnias e gêneros. Stuart Hall é taxativo ao indicar que "em vez de pensar as culturas nacionais como unificadas, deveríamos pensá-las como constituindo um dispositivo discursivo que representa a diferença como unidade ou identidade (HALL, 2006, p. 62).

Para seguir adiante será necessário ter isso em mente, seguido de um cuidado. Como na favela do Jacarezinho, temos a predominância de afro-brasileiros, é difícil pensar em um discurso unificador que prevaleça integrado a uma identidade nacional em torno da raça. As ideologias racistas não estavam mais fundamentadas em características biológicas como no início do século XX, que defendiam a superioridade da "raça branca", mas em atributos discursivos centrados em diferenças físicas e comportamentais pouco específicas. O argumento de Gilroy (1992, p. 87) sobre as ligações entre o racismo cultural e as ideias de nação e pertencimento atesta que o racismo "...constrói e defende uma imagem de cultura nacional - homogênea na sua branquidade, embora, precária e eternamente vulnerável ao ataque dos inimigos internos e externos...". Assim como ocorreu com a Europa, a formação das nações é de sangue misto. Renan (1990, p. 14- 
15) lembra que a França é ao mesmo tempo, germânica, céltica e ibérica; a Alemanha é germânica, céltica e eslava. A Itália, reúne gauleses, etruscos, pelagianos e gregos.

Então não temos tal coisa que possa ser chamada de cultura unificada, senão no discurso ou na imaginação. A favela não se vê integrada à cultura da identidade nacional pelo reconhecimento de sua condição natural de raça ou origem, mas pela posição social que cada morador ocupa no sistema de valores capitalista e nas expressões artísticas, por exemplo. As fábricas, e principalmente o samba e a política serão os sentidos de um cortejo pelos quais a efervescente coletividade negra da favela vai tentar resgatar o seu lugar de pertencimento.

Em relação às indústrias, Thiago (2007, p. 75-80) testemunha esta trajetória, observando como a General Electric e a Cisper tornam-se patrocinadoras das escolas de formação básica instituídas pela Igreja N.S. Aparecida. A GE investiu no Instituto de Educação que funcionava próximo ao acesso da fábrica, pelo lado de Maria da Graça e alcançava também as crianças de Cachambi. Outra escola foi estabelecida dentro do Jacarezinho, na própria igreja, com investimentos da Ordem dos Salesianos, da GE e da Cisper. Ambas as instituições eram privadas, mas funcionavam com bolsas fornecidas pelas empresas aos filhos dos empregados, em sua maioria. Por meio da Fundação Leão XIII, a General Electric ainda financiava cursos profissionalizantes para os que atingissem o nível médio de escolaridade, garantindo assim, qualificação e mão-de-obra para a própria fábrica.

A pesquisadora comenta que embora esta relação criasse vínculos positivos entre os moradores e as grandes indústrias mantenedoras dos projetos de educação e empregabilidade, surgiu paralelamente um sentimento de consciência crítica quanto ao grau de imobilidade social que a dependência de emprego, renda e educação causava nas famílias em relação a estas corporações. Este posicionamento ganhava em amplitude à medida que um movimento político de esquerda começa a crescer no Jacarezinho, estimulando lideranças comunitárias a se lançar no jogo político em defesa de seus próprios direitos, criando uma espécie de desintermediação entre a comunidade e o poder público desde a criação do Estado da Guanabara, em 1960. Esta era uma situação comum às principais favelas da zona norte, que também começavam a crescer em volta das indústrias. 
Quanto ao segundo aspecto, os desfiles das escolas de samba potencializaram para vários blocos e pequenas escolas suburbanas, a oportunidade de crescer e materializar o sonho de uma performance profissional na avenida Rio Branco, que sediava os desfiles até 1984, antes da criação do Sambódromo. Em 1966 surge a Unidos do Jacarezinho, resultado da junção da Unidos do Jacaré e Unidos do Morro Azul. O bloco Não Tem Mosquito permaneceu como bloco, mas a partir desta fusão e do seu crescimento, o samba passa a se constituir em opção de lazer com a frequência dos moradores à quadra da nova Escola de Samba. Um dos motivos de orgulho para a comunidade, segundo a pesquisadora, é a participação do sambista Monarco (Hildemar Diniz), como compositor da escola. Um dos sambas-enredo mais marcantes composto por ele foi "Vila Rica do Pilar" (1969) que levaria a escola de samba a desfilar no grupo principal em 1970 (THIAGO, 2007, p. 80-82).

Coerentemente ao que Velloso (1996) afirmava sobre a importância das expressões culturais "subalternas" do início do século XX, como elementos formadores da modernidade carioca, o samba contribuiu de forma significativa para a formação da identidade das favelas para além da "cidade civilizada". Assim como Velloso (1996) reiterava que por intermédio das ruas foi sendo reconstruída parte da história e da memória da cidade, por outro lado, por meio das rodas de samba nas favelas foi possível capturar o elemento catalizador da identidade e da memória destas comunidades. Os personagens e as histórias que transitavam nas abordagens de Velloso, a respeito da modernidade do Rio no início do século XX eram o comerciante português e a mulata empregada, além dos tipos de Magalhães Junior (1973): selistas, ciganos, tatuadores e trapeiros $^{13}$. Atualizando esta tipologia, o sentido de marginalidade aplicado sete décadas depois ao ambiente da favela. inclui agora as suas figuras típicas: o vagabundo, o passista, o bicheiro, o moleque do beco e a mulata do samba. O imaginário de grande parte dos moradores do Jacarezinho captava as rodas de samba nos "botecos" da esquina, os ensaios e eventos na quadra da escola e os possíveis desfiles no grupo principal como dinâmicas cotidianas, nas quais a vida social e intelectual dava conta de

13 Ver Magalhães Junior, Raimundo de. Estrutura social da República das Letras: sociologia da vida intelectualbrasileira - 1870-1930. São Paulo: USP/Grijalbo, 1973 
um sentido de pertencimento poderoso e arrebatador. Algo estava mudando na favela industrial em meio à nova identidade que parte dos moradores forjava para si.

Por fim, a questão política é mais complexa. Desde 1955, a Igreja Católica atuava nas favelas através da Cruzada São Sebastião por meio do Bispo Auxiliar D. Hélder Câmara, com o propósito de urbanizar as favelas, mas também de "cristianizar". Este termo pode ser interpretado de várias maneiras, contudo se seguirmos a cartilha das ordens religiosas católicas no Brasil, não fica longe de constatarmos a construção de um tecido ideológico que misturava catequese, mediação social e mobilização política. O pano de fundo da criação da Cruzada era transformar o seu projeto em modelo para uma meta mais ambiciosa do então bispo auxiliar: erradicar em dez anos as 150 favelas existentes na cidade. O passado de D. Hélder ligado aos integralistas e sua mobilização por direitos sociais, sinalizava para um tipo de envolvimento dos padres que passou a ser comum nas comunidades carentes da cidade a partir dos anos 1960: uma mistura de interlocutor e ativista político.

O sociólogo José Arthur Rios, coordenador do Serviço Social do governo Carlos Lacerda, atuava nesta época na área de favelas como o primeiro pesquisador neste campo. Em entrevista concedida em 2002, ao CPDOC - Centro de Pesquisa de Documentação de História Contemporânea do Brasil, da FGV ${ }^{14}$, revelou que como articulador político do governador era crítico do modelo defendido pela Igreja Católica, de construções verticais para erradicação das favelas. Ele as chamava de "guetos" por reproduzirem as mesmas lacunas da favela horizontal. Citava os institutos de aposentadoria que plantaram vários conjuntos residenciais "que se transformaram em focos de crime, drogas e prostituição". Na entrevista fez questão de frisar que a favela tinha outra possibilidade de realização, que o conjunto verticalizado não possuía. O conjunto em sua opinião, sufocava e não tinha nenhuma gerencia agindo internamente, como uma associação de moradores.

Lidar com as favelas era politicamente delicado no governo udenista de Carlos Lacerda, pois a maioria dos cabos eleitorais estava ligada ao PTB, partido adversário. Uma das

${ }^{14}$ Depoimentos ao CPDOC FGV - Capítulos da Memória do Urbanismo carioca, 2002. 
decisões mais polêmicas do secretário José Rios foi eliminar o contato entre favelados e os pretensos "benfeitores" políticos. Assim, ele pode nomear funcionários para redigir atas de fundação de 50 associações de moradores através de eleição direta. Políticos tradicionais como Sami Jorge, Geraldo Moreira, Amando da Fonseca, inimigos políticos de Lacerda, afrontaram o sociólogo e criaram embaraços. O governador e seu secretário social José Rios olhavam para os objetos próximos que envolviam as questões da favela, com visões diferentes, mas havia um ponto em comum. Ambos pensavam em termos de como a Igreja Católica foi se apropriando da função de representante das comunidades faveladas, em alguns casos intensificando as atividades para uma militância política engajada e por outro lado, de que modo a secretaria social poderia afastar estas lideranças, propondo em tese um alcance mais pragmático, estimulando as lideranças locais a dialogar diretamente com o poder público.

Os efeitos da ação religiosa no Jacarezinho, refletem parcialmente esse jogo político. $\mathrm{O}$ traçado desenhado pela Igreja N.S. Conceição, liderada pelo padre Nelson e o universo de políticos de ocasião, em tese, divergia da orientação dos princípios da Cruzada. Vimos como a liderança da igreja católica local se engajou na luta pela manutenção dos moradores na favela do Jacarezinho, o que de certo modo, contrariava os princípios preconizados pelo grupo de D. Helder Câmara, de realocar gradativamente as favelas. Pode-se creditar isso ao fato de que Padre Nelson preenchia o perfil de religioso "engajado politicamente", mas não se mostrava extremista. O fato da favela do Jacarezinho ter construído um tecido social complexo em mais de cinco décadas desde os primeiros barracos, combinado com o fato de D. Helder Câmara não desfrutar de unanimidade entre os bispos, também contribuiu para um cenário político híbrido. A despeito disso, parece inegável, ter havido uma disputa entre a Igreja e o Estado pelo controle da atuação nas favelas, ou na melhor das hipóteses, uma hostilidade entre D. Helder Câmara e o governador Lacerda.

Quanto a este aspecto, a existência de uma ordem jurídica oficial que deveria se sobrepor a estrutura sociojurídica da comunidade capitaneada pela Igreja, remonta aos estudos empíricos que o sociólogo português Boaventura Santos realizou anos mais tarde, quando morou na própria comunidade em 1970, na preparação para seu 
doutoramento em Sociologia do Direito, na Yale University. Em sua obra "O direito dos oprimidos" (2014 [1973]) resultante destes estudos socioantropológicos no Jacarezinho, o pesquisador lança seu olhar sobre como o Estado-Nação brasileiro convivia com a existência paralela de ordenamentos jurídicos fora do seu alcance, como nas favelas, por exemplo, e ao mesmo tempo contrapunha-se ao monopólio estatal do direito institucionalizado.

Constatando que a Associação de Moradores teria sido criada para ofertar minimamente algum ordenamento administrativo e civil baseado em um tipo de governança popular comunitária, na verdade, ele supunha uma situação oposta, na medida em que a autoridade desta instituição estaria sendo ameaçada pelo regime autoritário da ditadura militar à época. (SANTOS, 2014, p. 346)

O autor reforça que não somente a Associação de Moradores, mas as igrejas, autoridades policiais, líderes comunitários e políticos elaboraram diferentes instancias de deliberação informal que diziam respeito tanto às práticas sociais e costumes locais até as circunstancias de resolução de litígios, para os quais não eram levados em conta a ética e o direito estatal. (SANTOS, 2014, p. 348).

É de se presumir que este funcionamento marginal do direito na favela do Jacarezinho poderia direcionar as pesquisas de Santos para uma visão etnocêntrica, afinal tratava-se de um europeu mergulhado na favela e pesquisando para uma universidade americana, o que não ocorreu efetivamente. Antes dele, as culturas particulares do tipo favela, não tinham sido objeto de tal tratamento epistemológico, contudo o delineamento de sua pesquisa circunscrito a sistematização jurídica, talvez tenha impossibilitado uma descrição da totalidade singular dos fatos culturais a fim de compreendê-los conjuntamente. Teria faltado no seu texto a síntese original que representou na emergente cultura desta favela a elucidação do vínculo que ligava o indivíduo a sua cultura local. As ações políticas e religiosas de fundo continuavam a dar maiores explicações sobre isso.

Antes de sua visita, no final dos anos 1960, sob influência da ditadura militar, assistimos a introdução do bipartidarismo no Brasil restringindo as disputas políticas entre os partidos Arena e MDB. A hibridez política no Jacarezinho vai cedendo lugar a uma 
divisão mais explícita com o impulso de um movimento de extrema esquerda liderado por membros do MDB, adeptos do comunismo e integrantes da ala progressista da Igreja Católica. Os tempos de Lacerda tinham ficado para trás substituídos pelos militares e o chaguismo. Em meio à ditadura, a Associação de Moradores engajou-se na luta política, concentrando as disputas entre dois grupos do MDB: os chaguistas (ligados ao governador Chagas Freitas) e os autênticos (formado por extremistas comunistas, membros do MR-8 ou apoiadores de D. Hélder). As contendas entre estes grupos políticos perduraram até o brizolismo surgir nos anos 1980, mas giravam não somente em torno dos temas operários, mas também das demandas mais imediatas como manilhamento e iluminação. Mais tarde cerraram fileiras em torno de empenhos para o asfaltamento das ruas, saneamento e a canalização do Rio Jacaré.

A partir das pistas sugeridas no estudo de Cristiane Thiago, com a anistia política de 1979 e a eleição do governador Leonel Brizola, o núcleo regional do PDT vai disputar espaço político com o PT na favela. Uma parte dos extremistas, também chamados de Grupo Amarelo, inclinou-se para um discurso independente mantendo-se em torno do MR-8 e outra parte foi se aproximando do Partido dos Trabalhadores. Quem toma a dianteira, entretanto, no Jacarezinho é o PDT, herdando o legado do chaguismo através da atuação de políticos como Hilza e Laercio Mauricio da Fonseca. Não seria equivocado dizer que depois do domínio do "chaguismo", iniciou-se no Jacarezinho dos anos 1980 a era do "brizolismo". Um dos fatos que ajudou nesta identificação foi a canalização do Rio Jacaré, concluída no governo Brizola.

Enquanto isso, as fábricas estavam sendo desativadas por inúmeros motivos e as temáticas operárias em torno delas, estavam sendo substituídas por discussões mais ideológicas, centradas nos direitos dos trabalhadores como emprego, salário, saúde e educação. O Jacarezinho abraçava a era da globalização política, abrindo-se para os temas mais universais ainda que mesclados ou espelhados nas reinvindicações locais. As identidades tradicionais construídas em torno das fábricas, do samba e da luta política se esfacelavam para dar lugar às múltiplas identidades da pós-modernidade.

Deste modo, na primeira década do novo milênio as demandas na área das ciências sociais voltavam-se para a defesa dos direitos de inclusão e cidadania dos indivíduos ou 
grupos, ao invés de bairros, comunidades ou nações, em conformidade com as temáticas estimuladas por órgãos como o Fórum Econômico Mundial e o Fórum Social Mundial15. Buscando uma associação entre esta tendência e os estudos do presente artigo, podemos destacar a pesquisa de Jocelene Ignácio (2011), que em sua tese de doutorado para a PUC ${ }^{16}$, utilizou a experiência de moradores selecionados da favela do Jacarezinho como estratégia para identificar uma série de fatores que criariam barreiras físicas e reforçariam as fronteiras simbólicas capazes de deslocar os moradores de favela para um mundo à parte daquele considerado convencional.

A autora defende que a institucionalização e a consequente naturalização do conceito negativo relacionado a favela potencializaram a sustentação dos estigmas atribuídos aos seus moradores.

\begin{abstract}
Os moradores da favela veem os símbolos culturais e os significados que thes são imputados como descrições de categorias diretamente vinculadas à "identidade" de favelado; identidade assumida por eles mesmos ou atribuída por outros, com o propósito de diferenciá-los, e não de integrá-los ou igualálos, no sentido de implicar o pertencimento a um grupo. O uso deste tipo de vínculo identitários é acionado apenas para determinar sua in-exclusão por parte do grupo dominante, ou seja, tais "rótulos" têm de ser aplicados para que, em determinadas situações, seja possível explicar supostas diferenças socioculturais, no lugar de revelar, destacar e potencializar as qualidades (IGNACIO, 2014, p. 57)
\end{abstract}

Este estigma é reforçado pelo próprio poder público, por exemplo, quando no Plano Diretor da cidade de 1992 ou nas classificações de "favela" do IBGE 2000, as menções são pejorativas não somente em relação a topografia e descrição física, mas igualmente nos ideários discriminatórios e segregacionistas. Na interpretação da autora, esses limites estão em conformidade com vários cientistas sociais que ao longo de sua tese, não somente defendem que estas fronteiras são socialmente construídas, como também afirmam que as classificações e distinções são estabelecidas em um jogo de poder entre os moradores da favela e os do "asfalto".

\footnotetext{
15 O Fórum Econômico Mundial é uma instituição sem fins lucrativos com sede em Genebra, conhecida por suas reuniões anuais em Davos, Suíça - reunindo os principais líderes empresariais. O Fórum Social Mundial é um evento elaborado por movimentos sociais, para fomentar alternativas de transformação social global.

${ }^{16}$ A tese de doutorado: "Doutores, mas não-cidadãos? Trajetórias de vida de egressos do ensino superior, moradores da favela do Jacarezinho - Rio de Janeiro 2000 a 2009" foi submetida a PUC em 2011 com o objetivo de subtrair os conteúdos do discurso universitário que insistia em negligenciar a existência de status no mundo acadêmico e profissional aos grupos marginalizados das favelas, especialmente os negros.
} 
No seu texto, a favela do Jacarezinho transparece mais como uma ponte temática, não necessariamente um estudo aplicável especificamente à comunidade. A identidade que a autora analisa não está referenciada no bairro, mas nas contendas globais de moradores de qualquer favela, vale dizer na luta dos espaços populares contra os elementos capazes de validar o mito da marginalidade direcionado aos moradores. Como o estudo de Jocelene Ignacio está voltado especialmente para reconhecimento dos universitários e doutores oriundos da favela e de bairros pobres de baixa renda nas cidades brasileiras, este cenário de deslocamento das identidades, típico do final do século XX e início do século XXI, sinalizava uma alteração dos estudos e discursos sobre a favela. Em detrimento dos que vocalizam os moradores de favelas pelos olhos descritos do poder público e setores midiáticos, a partir dos novos atributos ao centrar nossas análises na favela e nos problemas experienciados por estudantes pobres, pode-se delinear uma alegoria da pobreza urbana.

\section{Nós, os favelados do asfalto.}

Nos anos 1990 e 2000 consolidam-se três movimentos interdependentes, nos quais causa e efeito se misturam. Em primeiro lugar, a consolidação da saída das indústrias do Jacaré acarreta aumento das taxas de desemprego no local, até então mantidas em nível acima da média dos bairros do Rio. A despeito da situação econômica do Brasil nos anos 1990 e das exigências de modernização face às novas técnicas de fabricação e instalação exigidas para os complexos industriais, os índices de violência identificados em toda a região do Jacarezinho, Manguinhos e Benfica ao longo dos anos 1990 e 2000 pode ter sido o fator decisivo para a saída da maior parte das indústrias da região. Uma lista das mais importantes deve incluir: Fábrica de parafusos Águia, Moinho de Ouro, Supercor, Fábrica de roupas Company, Sadia e Laboratório Glaxo Welcome, sem falar nas gigantes General Electric em Maria da Graça, Gillette e CCPL (Cooperativa Central dos Produtores de Leite) em Benfica. A Fábrica de Tecidos Nova América em Del Castilho, fechada em 1991, transformou-se em um shopping em 1995. Somaram-se a essas grandes companhias, outras inúmeras empresas de pequeno porte entre metalúrgicas, laboratórios e fábricas de bens de produção. 
O caso mais emblemático foi a saída da multinacional General Electric em 2008. Em reportagem publicada meses antes em um grande jornal, a companhia alegava que o motivo do encerramento das atividades decorria da reestruturação internacional da corporação por meio da qual já teriam sido "fechadas fábricas ou demitidos funcionários nos EUA, Europa e México. A reestruturação teve início no ano passado, com o fechamento de uma unidade de lâmpadas no Chile" (DANTAS, 2007) ${ }^{17}$. Não havia referências à violência crescente da favela ao lado, uma vez que na verdade, o principal motivo teria sido a concorrência chinesa que asfixiava as fábricas da GE. A reportagem assinala terem sido observadas taxas decrescentes de rentabilidade no segmento de lâmpadas abreviando a continuidade do negócio. Após quase 90 anos, tendo sido protagonista do processo de atração e imigração de moradores para a favela, a GE experimentava a sensação inversa de contribuir para o aumento da taxa de desemprego na região industrial do Jacaré e entorno.

Em segundo lugar, verificamos um novo fenômeno de ocupação urbana que se tornou comum nos demais bairros da zona norte. Até 1990, a favela do Jacarezinho conformava-se em um território aproximadamente retangular limitado entre o Rio Jacaré e os muros da General Electric. A partir da Rua Miguel Ângelo ou do "Buraco do Lacerda"18, chegava-se ao limite norte - a Av. D. Helder Câmara. Este traçado foi sendo ampliado para assumir a forma de um polígono côncavo, à medida que nas áreas limítrofes das antigas indústrias, tanto no lado Leste (Rua Bráulio Cordeiro, Jacaré e Benfica) como no lado Sul (entorno da Rua Lino Teixeira e Engenho Novo) foi identificado um novo e progressivo processo de ocupação. Galpões, instalações de fábricas e construções de alvenaria foram literalmente tomados, após serem abandonados nos espaços encravados entre os limites originais da favela e os antigos sítios industriais.

A favela encontrou finalmente um meio de expansão horizontal ao longo das ruas Bráulio Cordeiro, Viúva Cláudio, Dois de Maio, Souza Barros e adjacências, fazendo

17 Depoimento prestado ao jornalista Eurico Dantas, da Folha de São Paulo, em 29 jun 2007.

18 O governador Carlos Lacerda (1961-1965) construiu a passagem de nível que liga a Avenida Dom Hélder Câmara à Rua Bráulio Cordeiro, na Favela do Jacarezinho. 
surgir os "favelados do asfalto" - pequenos núcleos e "puxadinhos" horizontais" erguidos nas ruas. Estes embriões derivaram para novas favelas: Pica Pau Amarelo, Carlos Drumond de Andrade, Vila Jandira ou Favela da Xuxa, Morrinho, Dois de Maio e Malvinas, culminando com o surgimento do termo "Complexo de Jacarezinho" que o Censo Demográfico do IBGE de $1991^{20}$ utilizou para caracterizar o novo patamar sociodemográfico da favela.

Por último, a posse da favela por uma facção do tráfico instala uma nova ordem social pautada pelo ambiente de consumo generalizado de drogas e embates com a polícia. $\mathrm{Na}$ esteira do projeto de instalação das UPPs (unidades de polícia pacificadora) que visava minimizar o controle territorial destas facções e instalar projetos sociais, os meios de comunicação criticavam aquilo que o jornalista Felipe Betim do jornal El Pais registra como "projeto político e econômico".

ao contrário da favela Santa Marta, o braço social do programa, chamado de UPP social, não saiu do papel. A maioria das favelas continuaram carentes de serviços públicos do Estado e nunca tiveram investimentos em infraestrutura, sobretudo em saneamento básico. (BETIM, 2018).

Este quadro sugere que embora a UPP social tenha conseguido realizar um diagnóstico consistente, restringiu-se a um pacote teórico. O correspondente do jornal espanhol salienta que estas unidades de pacificação eram instaladas em localidades de maior visibilidade, com retorno garantido nos meios de comunicação e esse fato geraria maior desigualdade, na medida em que os territórios da zona oeste não teriam investimento social e presença das forças de segurança. A UPP Jacarezinho foi instalada em 2013, uma das últimas da lista divulgada pelo ISP - Instituto de Segurança Pública do Rio de Janeiro $^{21}$. Na verdade, a distribuição destas unidades foi sendo disseminada ao longo do tempo por várias comunidades mais pobres da zona oeste, mas devemos concordar com o articulista que os investimentos deveriam ter sido guiados por critérios sociais. $\mathrm{Na}$ trajetória midiática da cidade rumo à Copa do Mundo e às Olimpíadas, o projeto teria

19 Construção informal e irregular, em forma de extensão ou anexo em um imóvel utilizado pela população de baixa renda para tentar resolver o problema de espaço (Censo Demográfico 1991)

20 Os aglomerados Dois de Maio e Malvinas, mais distantes, foram incluídos pelo Censo Demográfico do IBGE como integrantes do Complexo do Jacarezinho, por causa do "estrangulamento" da favela.

21 No balanço de indicadores da política de pacificação, o ISP - Instituto de Segurança Pública RJ registrava a instalação de 37 UPPs entre 2008 e 2014. 
servido para tornar o Rio uma cidade de turismo e negócios, encapsulada em um programa governamental de viés econômico.

O geógrafo e urbanista Peter Hall (1988) dedicou parte de seus estudos ao crescimento e à mudança nas cidades, analisando o fenômeno da desorganização e empobrecimento do espaço urbano no século XX, como uma extensão dos problemas herdados do século anterior. Ele focava nas cidades europeias e americanas, preocupado com o bem-estar social obtido através do planejamento urbano e rural visto como expressão do direito ao desenvolvimento. Incluía Londres, Paris, Berlim e Nova York, como as "cidades encortiçadas" do final do século XIX, alertando para a expansão do subúrbio por meio da dilatação do sistema de transportes.

Surgiram novos questionamentos, como por exemplo, o que foi proposto por Richard Rogers e Philip Gumuchdjian (1995) sobre os modelos urbanos da cidade difusa e cidade compacta. A cidade dispersa seria uma cidade na qual o seu desenvolvimento urbano ocorre priorizando o enfoque territorialista extensivo, ou seja, a cidade que se espalha em grandes territórios sem qualidade no tecido urbano, apresentando grandes vazios urbanos e uma série de serviços espraiados pelo seu território, com baixa conectividade. Tomando como base a descrição, poderíamos citar como exemplo de cidades difusas: Los Angeles, São Paulo, Cidade do México e Rio de Janeiro.

Neste sentido, a favela do Jacarezinho é resultante deste processo de extensão territorialista que ocorria no Rio de Janeiro por meio do deslocamento das indústrias do núcleo central da cidade para os subúrbios. Maurício de Abreu (1987) registra que na década de 1930 o Estado do Rio de Janeiro começa a intervir no processo de localização industrial por meio do Decreto-Lei 6.000/37, que definiu pela primeira vez uma área industrial na cidade. A zona sul e a maior parte da zona norte foram excluídas deste perímetro, exceto as regiões de São Cristóvão, Jacarezinho, Bonsucesso e Ramos. Outra área abrangia parte da Avenida Automóvel $\mathrm{Club}^{22}$ e outras faixas ao longo das estradas de ferro Central do Brasil, Linha Auxiliar (Del Castilho até Costa Barros) e Rio D'Ouro. O autor ressalta que este foi um período caracterizado pelo anarquismo da implantação

22 Designação popular da Avenida Pastor Martin Luther King Jr. 
industrial na área dos subúrbios através do aproveitamento de terrenos baldios e a conversão de antigos casarões residenciais.

Ao contrário desta descrição, na cidade compacta, a infraestrutura e os equipamentos urbanos são potencializados evitando-se o uso ineficiente do espaço e longos deslocamentos, uma vez que há infraestrutura de qualidade (transporte, comércio, serviços, cultura e habitação). Essa situação também é mais sustentável pela substituição dos investimentos na infraestrutura existente: energia elétrica, água ou esgoto. Nas circunstâncias descritas neste modelo o ideal de toda concentração urbana poderia ser a "cidadania ativa e vida urbana vibrante, componentes essenciais para uma cidade e uma boa identidade cívica" (ROGERS e GUMUCHDJIAN, 1995, p. 16). Se esta proposição for aceita, estes pontos ficam comprometidos no ambiente social para o qual o qual o Jacarezinho foi se encaminhando nos últimos 30 anos.

Nas últimas décadas do século $\mathrm{XX}$, verificamos que nas grandes metrópoles, os atos governamentais e o discurso dos meios de comunicação de massa reuniam em torno de si fragmentos dispersos do tecido urbano, como as favelas, mas que eram lidos como totalidades deste espaço. O discurso que se constrói destes ambientes ainda hoje é tomado como representativo de uma cidade inteira. A imagem da cidade do Rio de Janeiro é fortemente associada a estas comunidades, ainda que representem menos de $30 \%$ de seu território.

Em meio a esta polifonia, sobressaia a percepção de que talvez a cidade contemporânea somente conseguiria afirmar sua identidade de forma integral por alguns momentos, em terremotos, enchentes, atentados terroristas ou plebiscitos. Aceitando este argumento, as formas de reconstruir sentimentos de unidade nas engrenagens culturais e sociais sobreviveram nos espaços atomizados como núcleos étnicos, religiosos, bairros de imigrantes ou favelas. Nestes conglomerados, ficava-se mais próximo de uma identidade particular por causa dos centros de influência econômica e social ainda serem predominantemente locais, como ocorreu com o Jacarezinho até a década de 1980.

Esta situação vem sofrendo alterações desde 1990, carregando no DNA destas comunidades os vetores transnacionais externos discutidos por Nestor Canclini (2006, p. 85) e que se fazem presentes nas cidades da América Latina. Além da cidade industrial 
e da cidade histórica, Canclini fala da cidade globalizada "conectada com as redes mundiais de economia e comunicações", o que coloca os estudos urbanos focados não mais no processo de industrialização e suas consequências na rede tecnológico-cultural, mas nos processos informacionais e financeiros. As grandes cidades, despedaçadas pelo crescimento vertiginoso e convivendo com um multiculturalismo integrador e conflitante ao mesmo tempo, oferecem o cenário perfeito para o declínio das narrativas históricas, das utopias que na opinião de Canclini (2006, p. 121), imaginaram um "desenvolvimento humano ascendente e coeso através do tempo". Deste modo, saem de cena os movimentos libertadores capitaneados pelo proletariado ou pelos discursos unificados de cidades ou nações e entram em cena os movimentos sociais urbanos, estilhaçados e fugazes.

Situando o Jacarezinho nesta encruzilhada, talvez possamos descrever agora um "espaço" que pode ser atravessado de forma fulminante, com estilhaços efêmeros de relações sociais, cuja forma visível pode esconder conexões mais distantes ou ausentes. Alguns exemplos: o funk vai se tornando protagonista nas praças de bailes, mas vai sendo suturado com o samba nos "botecos". A comercialização explícita das bancas de droga, é copiada de Tijuana (México). O comércio de pequenas lojas vai se expandindo pelas ruas vizinhas do Jacaré e Sampaio, muitas delas patrocinadas ou protegidas pelas milícias ligadas ao tráfico. A Associação de Moradores não se organiza mais politicamente, pois não há mais causas políticas locais a defender: as demandas são aquelas capitaneadas pela mídia transnacional: emprego, salários, cidadania dos excluídos, direitos de camelotagem nas ruas ou qualidade do transporte público. A proliferação de seitas religiosas vem abafando as igrejas tradicionais e suas vozes são as mesmas em todo o lugar: fetiches de cura, discursos metafísicos e a mercantilização da fé não permitem espaços para padres ou pastores políticos, defensores das causas comunitárias, como antes. Grande parte das famílias encasteladas em seus barracos comprimidos, detestam a polícia e a ordem pública. Elaboram uma polifonia de sons estéreos portáteis em seus bailes de "música de sofrência" permeados pelo "pagode" e pelos gols do Flamengo, agora um time que também quer ser "global". 


\section{Conclusões}

É notório que o surgimento das favelas no Rio de Janeiro está inserido em um contexto amplo que tem origem no final do século XIX. No núcleo desta conjuntura sociopolítica, está a substituição do governo monárquico e a invenção da República que transformaram o centro da cidade no palco do lócus da modernidade e da identidade republicana projetadas para o país. Sem espaço neste novo projeto civilizatório, os pobres e pretos foram compelidos a ocupar os morros vizinhos. Ultrapassada esta fase, estimulados pela onda de industrialização que acometeu o governo federal no início do século XX, surgiram os primeiros eixos pobres em torno das fábricas na zona norte, favorecendo a expansão territorial das ocupações inauguradas nos morros da área central da cidade. A favela do Jacarezinho nasceu e cresceu estimulada em grande parte pela inauguração das fábricas da General Electric e da Cisper nos anos 1920.

O relato deste processo, composto de três etapas, preocupou-se não somente em descrever o desenvolvimento histórico e espacial, mas também a formação dos elos sociais que projetaram os símbolos constitutivos da identidade cultural do local.

Vimos que nas primeiras duas fases, até os anos 1980, mesmo que integrada a uma cultura nacional que teimosamente insistia em encapsular as favelas e as expressões particularistas das músicas, crenças e valores dos negros ou nordestinos na suposta identidade nacional multirracial e multicultural, o lugar permanecia ofertando escolhas de identidade razoavelmente concretas. Podia-se imaginar até "raízes" e construir mitos de origem como os jacarés encontrados no rio, ou a saudosa Fazenda Velha.

Este fato respondeu particularmente a nossa preocupação sobre como as identidades locais estariam a partir de meados do século XX sendo reforçadas pela resistência à globalização, e no caso do Jacarezinho, constatamos que as dimensões da vida social podiam ainda ser dominadas pela presença, por uma atividade localizada: a fábrica, o samba ou a política interna, ainda que sob a pressão dos padrões desiguais de troca cultural.

Constatamos pelo relato da terceira fase, que desde os anos 1990 está ocorrendo um novo deslocamento no acúmulo simbólico da identidade local, que parece refletir aquilo 
que está se sucedendo nas relações entre o global e o local, por conta da globalização. Nossa hipótese deve considerar que as identidades nacionais ou o discurso que se fazia delas estão sendo desintegradas, dando lugar a uma homogeneização cultural, que muitos autores identificam como "pós-moderna". Também é possível afirmar que enquanto as identidades unificadas estão declinando, novas identidades, mescladas estão tomando seu lugar.

Devemos levar em conta que aplicado ao Jacarezinho, este circuito desintegrou os laços de identidade cultural e social que se formaram originalmente na comunidade em torno das fábricas, das igrejas, do samba ou da Associação de Moradores. Ao mesmo tempo vem integrando a comunidade a um formato cujas características totalizadoras ainda parecem escapar da descrição pretendida neste escopo, sendo possível uma hipótese parcial.

À medida que a vida social na comunidade se tornou tutelada pela mercadologia globalizante de produtos, tendências, imagens de mídia digital, redes sociais e sistemas de comunicação, mais a identidade local se desprendeu dos tempos, lugares, narrativas e tradições que vinham sendo concebidas até 1980.

Os elementos desta investigação, tanto no domínio da sociologia como da Antropologia e Etnologia potencializam hipóteses férteis e abrem perspectivas para novas pesquisas sociais no futuro. A favela do Jacarezinho, como palco de estudos socioantropológicos, conforme descrito, suscita o interesse natural para tais projetos pois se tornou no Rio de Janeiro, o protótipo dos núcleos favelizados de aglomeração industrial que vieram posteriormente. Nossa hipótese ainda a ser confirmada é que talvez tenha sido a comunidade carioca que mais vem sofrendo os impactos da crise das identidades, que está deslocando os sistemas e processos culturais das sociedades contemporâneas e desestabilizando os quadros de referência que davam aos indivíduos uma sustentação estável no mundo social. 


\section{Referências}

ABREU, Jonas. Rio de Janeiro: a Batalha das identidades. Rio de Janeiro: Amazon, 2014.

ABREU, Mauricio de Almeida. Evolução urbana do Rio de Janeiro. Rio de Janeiro: IplanRio/Zahar, 1987.

ANDERSON, Benedict. Imagined Communities. Londres: Verso, 1983.

BARRETO, Paulo. As religiões no Rio. Rio de Janeiro: Editora Nova Aguilar, Coleção Biblioteca Manancial, n. 47, 1976.

BETIM, Felipe. UPPs: mais uma história de esperança e fracasso na segurança pública do Rio. El Pais, Madrid. 21 mar. 2018. Intervenção federal no Rio de Janeiro.

BRENNAN, Timothy. The nacional longing for form. In Bhabha, Homi (org.) Narrating the Nation. Londres: Routledge, 1990.

CANCLINI, Nestor Garcia. Consumidores e cidadãos. 6. ed. Rio de Janeiro: Editora UFRJ, 2006.

CECHTH. Owens Illinois - Sipat - Quick Massage. Disponível em: http://cecth.com.br/index.php?option=com_content\&task=view\&id=128\&ltemid=79.

Acesso em: 23 fev. 2020.

COURT. André de. Maria da Graça, fábrica da GE, déc. 20. Disponível em: https://rioquepassou.com.br/2011/03/30/maria-da-graca-fabrica-da-ge-dec-de-20/.

Acesso em: 22 fev. 2020.

DANTAS, Eurico. GE fecha fábrica de lâmpadas e cortará 900 no Rio. Folha de São Paulo, 29 jun. 2007, Mercado.

DATARIO. Instituto Pereira Passos. Breve relato sobre a formação das divisões administrativas na Cidade do Rio de Janeiro. Coleção Estudos Cariocas, 2010. Disponível em: http://www.data.rio/datasets/3f105a10dcf7475eae69b2514b9d6262. Acesso em 23 fev 2020.

GONÇALVES, Rafael Soares. Favelas do Rio de Janeiro: história e direito. Rio de Janeiro: Pallas / Editora PUC Rio, 2013.

HALL, Peter. Cidades do amanhã. São Paulo: Perspectiva, 1988.

HALL, Stuart. A identidade cultural na pós-modernidade. $11 \mathrm{a}$. Ed. Rio de Janeiro: DP\&A Editora, 2006.

FREIRE, Américo. OLIVEIRA, Lúcia Lippi. (Orgs.). Capítulos da memória do urbanismo carioca. Depoimentos ao CPDOC / FGV. Rio de Janeiro: Folha Seca, 2002. 232p.

GERSON, Brasil. História das ruas do Rio. 5ed. Rio de Janeiro: Editora Nova Aguilar, 2000.

GILROY, Paul. The end of anti-racism. In: DONALD, J.; RATTANSI, A. (Orgs.). Race, Culture and Difference. Londres, Sage, 1992. 
IGNÁCIO, Jocelene de Assis. Doutores, mas não-cidadãos? Trajetórias de vida de egressos do ensino superior, moradores da favela do Jacarezinho: Rio de Janeiro de 2000 a 2009. 2011. 153f. Tese (Doutorado em Serviço Social). PUC - Pontifícia Universidade Católica do Rio de Janeiro, Departamento de Serviço Social, 2011.

INSTITUTO DE SEGURANÇA PÚBLICA DO RJ. Unidades de polícia pacificadora: o que são. Disponível em: http://www.isp.rj.gov.br/Conteudo.asp?ident=62. Acesso em: 18 fev. 2020.

LUCENA, Felipe. As praias extintas da cidade do Rio de Janeiro. 21 dez 2020. Disponível em https://diariodorio.com/as-praias-extintas-da-cidade-do-rio-de-janeiro/. Acessado em 23 jul 2020.

NEVES, Magno. Denúncia na Rio+20: Passivo socioambiental deixado na cidade do Rio pela multinacional General Electric - G.E. Disponível em: https://acervo.racismoambiental.net.br/2012/06/16/denuncia-na-rio20-passivosocioambiental-deixado-na-cidade-do-rio-pela-multinacional-general-electric-g-e/.

Acesso em 22 fev. 2020.

OLIVEIRA, Lúcia Lippi. Cultura é Patrimônio. Rio de Janeiro: Editora FGV, 2008.

PORTAL GEORIO. Bairros Cariocas. Disponível em: Portalgeo.rio.rj.gov.br/armazenzinho/web/BairrosCariocas/main_bairro.asp?area=051. Acesso em: 26 mar. 2020.

POWELL. Enoch. Liberdade e realidade. Farnham: Elliot Right Way Books, 1969.

RENAN, Joseph Ernest. What is a nation? Im: BHABBA, H. (Org.). Narrating the nation. Londres: Routledge, 1990.

ROGERS, Richard; GUMUCHDJIAN, Philip. Cidades para um pequeno planeta. Rio de Janeiro: Editora GG BR, 2015.

SANTOS, Boaventura Souza. Direito dos oprimidos: sociologia crítica do direito. Parte I. São Paulo: Cortez, 2014.

TAVARES, Fábio. Jacarezinho.blogspot. Disponível em: https://jacarezinhorj.blogspot.com/p/fundacao-do-jacarezinho.html. Acesso em: 22 fev. 2020.

THIAGO, Cristiane Muniz. Rio de Janeiro operário: Memória dos trabalhadores do bairro do Jacaré. 2007. 133f. Dissertação de Mestrado. Programa de Pós-graduação em Memória Social, Universidade Federal do Estado do Rio de Janeiro - UNIRIO, Rio de Janeiro, 2007.

VELlOSO, Mônica Pimenta. Modernismo no Rio de Janeiro: turunas e quixotes. Rio de Janeiro: Editora FGV, 1996.

WEID, Elisabeth von der. O advento da Companhia (1900-1912) in: Maria Bárbara Levy e Eulália L. Lobo, org. Estudos sobre a Rio Light. Rio de Janeiro, Light Serviços de Eletricidade S.A., 1990, p. 41 